\title{
Role of Bed Nucleus of the Stria Terminalis Corticotrophin- Releasing Factor Receptors in Frustration Stress-Induced Binge-Like Palatable Food Consumption in Female Rats with a History of Food Restriction
}

\author{
Maria Vittoria Micioni Di Bonaventura, ${ }^{1}$ Roberto Ciccocioppo, ${ }^{1}$ Adele Romano, ${ }^{2}{ }^{\circledR}$ Jennifer M. Bossert, ${ }^{3}$ \\ Kenner C. Rice, ${ }^{3}$ Massimo Ubaldi, ${ }^{1}$ (D) Robyn St. Laurent, ${ }^{3}$ Silvana Gaetani, ${ }^{2}$ Maurizio Massi, ${ }^{1}$ Yavin Shaham, ${ }^{3}$ and \\ Carlo Cifani ${ }^{1,3}$ \\ ${ }^{1}$ School of Pharmacy, Pharmacology Unit, University of Camerino, I-62032 Camerino, Italy, ${ }^{2}$ Department of Physiology and Pharmacology, Sapienza University of \\ Rome, I-00185 Rome, Italy, and ${ }^{3}$ Intramural Research Program, National Institutes of Health/National Institute on Drug Abuse, Baltimore, Maryland 21224
}

\begin{abstract}
We developed recently a binge-eating model in which female rats with a history of intermittent food restriction show binge-like palatable food consumption after 15 min exposure to the sight of the palatable food. This "frustration stress" manipulation also activates the hypothalamic-pituitary-adrenal stress axis. Here, we determined the role of the stress neurohormone corticotropin-releasing factor (CRF) in stress-induced binge eating in our model. We also assessed the role of CRF receptors in the bed nucleus of the stria terminalis (BNST), a brain region implicated in stress responses and stress-induced drug seeking, in stress-induced binge eating. We used four groups that were first exposed or not exposed to repeated intermittent cycles of regular chow food restriction during which they were also given intermittent access to high-caloric palatable food. On the test day, we either exposed or did not expose the rats to the sight of the palatable food for $15 \mathrm{~min}$ (frustration stress) before assessing food consumption for $2 \mathrm{~h}$. We found that systemic injections of the CRF1 receptor antagonist R121919 (2,5-dimethyl-3-(6-dimethyl-4-methylpyridin-3-yl)-7 dipropylamino pyrazolo[1,5-a]pyrimidine) (10-20 $\mathrm{mg} / \mathrm{kg}$ ) and BNST (25-50 ng/side) or ventricular (1000 ng) injections of the nonselective CRF receptor antagonist D-Phe-CRF (12-41) decreased frustration stress-induced binge eating in rats with a history of food restriction. Frustration stress also increased Fos (a neuronal activity marker) expression in ventral and dorsal BNST. Results demonstrate a critical role of CRF receptors in BNST in stress-induced binge eating in our rat model. CRF1 receptor antagonists may represent a novel pharmacological treatment for bingeing-related eating disorders.
\end{abstract}

Key words: binge eating; BNST; CRF1 receptor antagonist; palatable food; R121919; stress and food restriction

\section{Introduction}

Binge-eating episodes, characterized by excessive intake of an abnormally high amount of food in a short time period, are characteristic of individuals diagnosed with binge-eating disorders, bulimia nervosa, and binge/purge subtype anorexia nervosa (American Psychiatric Association, 2013). Binge eating of caloric-rich palatable food is also a common behavioral characteristic of obese individuals

Received May 6, 2014; revised June 26, 2014; accepted July 14, 2014.

Author contributions: M.V.M.D.B., R.C., M.M., Y.S., and C.C. designed research; M.V.M.D.B., A.R., J.M.B., R.S.L., and C.C. performed research; A.R., J.M.B., K.C.R., M.U., and S.G. contributed unpublished reagents/ analytic tools; M.V.M.D.B., A.R., J.M.B., Y.S., and C.C. analyzed data; M.V.M.D.B., R.C., S.G., M.M., Y.S., and C.C. wrote the paper.

The behavioral and pharmacological part of the research was supported by Italian Ministry of University and Research Grant FIRB-RBFR12DELS (C.C., S.G.). The synthesis of R121919 and the immunohistochemistry part of the research were supported by the National Institute on Drug Abuse, Intramural Research Program, and the National Institute on Alcoholism and Alcohol Abuse. We thank Dr. David Epstein for helpful comments on the text.

The authors declare no competing financial interests.

Correspondence should be addressed to Dr. Carlo Cifani at University of Camerino School of Pharmacy, Pharmacology Unit via Madonna delle Carceri, 962032 Camerino (MC), Italy, E-mail: carlo.cifani@unicam.it; or NIH/NIDA, Behavioral Neuroscience Branch, 251 Bayview Boulevard, Baltimore, MD 21224, E-mail: carlo.cifani@nih.gov.

DOI:10.1523/JNEUROSCI.1854-14.2014

Copyright $\odot 2014$ the authors $\quad 0270-6474 / 14 / 3411316-09 \$ 15.00 / 0$
(Yanovski, 1993; Hudson et al., 2007). In recent years, investigators have developed rat models of binge eating to study underlying mechanisms (Hagan et al., 2002; Corwin and Buda-Levin, 2004; Avena et al., 2008; Cottone et al., 2008; Cifani et al., 2009). In our studies, we use female rats because of the high prevalence of binge-eating disorders in adolescent and young adult females (Kjelsås et al., 2004; Hudson et al., 2007).

In our binge-eating model, we expose female rats to three 8 -day cycles of food restriction ( 4 days at $66 \%$ of chow intake and 4 days of free feeding) during which we also give them access to palatable food for $2 \mathrm{~h}$ on days 5-6 and 13-14. On the test day, we assess palatable food intake for $2 \mathrm{~h}$ after $15 \mathrm{~min}$ exposure to the sight of the food (Cifani et al., 2009). This "frustrative nonreward" manipulation (Amsel, 1958) or "frustration stress" manipulation, in combination with cycles of food restriction/refeeding, causes "binge-like" palatable food consumption during the first 15 min of the $2 \mathrm{~h}$ feeding test (Cifani et al., 2009, 2010; Micioni Di Bonaventura et al., 2012). We operationally define "binge eating" in our model as significantly higher palatable food consumption during the $2 \mathrm{~h}$ test in the repeated restriction plus frustration 
stress condition than in the other experimental conditions (see Materials and Methods).

We found previously that the anticonvulsant drug topiramate (which showed some efficacy in the treatment of binge-eating disorders in patients (McElroy et al., 2004) and orexin-1 receptor antagonists decrease stress-induced binge eating (Cifani et al., 2009; Piccoli et al., 2012). Here, we determined the role of the stress neurohormone corticotropin-releasing factor (CRF) in food restriction/frustration stress-induced binge eating in our model.

CRF mediates behavioral and physiological stress responses via its effects on both the hypothalamic-pituitary-adrenal (HPA) axis and extrahypothalamic brain sites (Vale et al., 1981; Bale and Vale, 2004). We determined the role of CRF in binge eating induced by the combination of cyclic food restriction and stress because human binge eating is associated with high cortisol levels (Gluck et al., 2004a,b; Coutinho et al., 2007), and stress-induced increases in cortisol levels predict sweet food intake (Epel et al., 2001). Additionally, we found that our frustration stress manipulation increases plasma levels of the stress hormone corticosterone (Selye, 1976), suggesting that this manipulation is stressful to rats (Cifani et al., 2010). These data are in agreement with results from early studies demonstrating that the removal of contingent (extinction) or noncontingent food reward (a frustrative nonreward manipulation; Amsel, 1958) increases plasma corticosterone, suggesting that unexpected reward omission induces a stress-like state (Coe et al., 1983). Finally, Cottone et al. (2009) demonstrated that withdrawal from intermittent palatable food access causes withdrawal-like symptoms (decreased motivation to obtain regular food and anxiety) that are reversed by injections of the CRF1 receptor antagonist R121919 (2,5-dimethyl-3-(6dimethyl-4-methylpyridin-3-yl)-7 dipropylamino pyrazolo[1,5a]pyrimidine) (Heinrichs et al., 2002).

Here, we first determined the effect of systemic injections of R121919 on binge eating in our model. We also determined the role of CRF receptors in bed nucleus of the stria terminalis (BNST) in binge eating and whether the frustration stress manipulation increases BNST neuronal activity, as assessed by the neuronal activity marker c-Fos (Morgan and Curran, 1991). We studied the BNST because of the role of CRF in this brain area in food consumption (Ciccocioppo et al., 2003), stress responses (Davis et al., 2010), and stress-induced drug seeking (Erb and Stewart, 1999; Erb et al., 2001; Bossert et al., 2013).

\section{Materials and Methods}

\section{Subjects and diet composition}

Female Sprague Dawley rats (Charles River; total $n=296 ; 200-225 \mathrm{~g}$ at the beginning of the experiments) were used. Rats were housed under a $12 \mathrm{~h}$ light/dark cycle (lights on at 8:00 A.M.) with access to food and water ad libitum for 2 weeks before the experiments. They were kept in a room at constant temperature $\left(20-22^{\circ} \mathrm{C}\right)$ and humidity $(45-55 \%)$. Rats were housed individually in metal cages $(30 \times 30 \times 30 \mathrm{~cm})$. All experiments were performed in accordance with the European directive 86/609/EEC governing animal welfare and protection, which is acknowledged by Italian Legislative Decree (number 116, January 27, 1992). The experiments were also performed in accordance with the Guide for the Care and Use of Laboratory Animals (eighth edition).

The rats were given standard rat food pellets (4RF18; Mucedola; 2.6 $\mathrm{kcal} / \mathrm{g})$. The highly palatable food $(3.63 \mathrm{kcal} / \mathrm{g})$ was a paste prepared by mixing Nutella (Ferrero) chocolate cream (5.33 kcal/g; 56, 31, and 7\% from carbohydrate, fat, and protein, respectively), ground food pellets (4RF18), and water in the following w/w percent ratio: $52 \%$ Nutella, $33 \%$ food pellets, and $15 \%$ water. Standard pellets were offered inside a metallic grid container that was hung on the anterior wall of the cage. The highly palatable food diet was offered in a coffee cup; the handle of the cup was inserted into the metallic grid of the anterior wall of the cage and fixed to the wall.

\section{Drugs}

The selective CRF1 receptor antagonist R121919 (Keck et al., 2001; Heinrichs et al., 2002) was synthesized by Kenner C. Rice (National Institute on Drug Abuse, Bethesda, MD). R121919 was dissolved in $1 \mathrm{~m} \mathrm{HCl} \mathrm{(10 \%}$ of final volume) and then diluted with a vehicle of $20 \%(\mathrm{w} / \mathrm{v})$ 2-hydroxypropyl- $\beta$-cyclodextrin (Sigma-Aldrich); the $\mathrm{pH}$ of the solutions was adjusted to 4.5 with $\mathrm{NaOH}$. R121919 was injected subcutaneously ( $2 \mathrm{ml} / \mathrm{kg}$ ) at doses of 10 or $20 \mathrm{mg} / \mathrm{kg}$ (Funk et al., 2007; Cottone et al., 2009).

The nonselective CRF receptor antagonist D-Phe-CRF (12-41) $_{\text {(Men- }}$ zaghi et al., 1994) was purchased from Bachem and dissolved in saline. The drug was injected bilaterally into the BNST at doses of 10,25 , or 50 $\mathrm{ng} / \mathrm{rat}(0.5 \mu \mathrm{l} / \mathrm{side})$ or into one of the lateral ventricles $(1 \mu \mathrm{l})$ at doses of 100, 300, or $1000 \mathrm{ng} /$ rat (Shaham et al., 1997; Erb et al., 1998; Erb and Stewart, 1999; Lê et al., 2002). We used D-Phe-CRF ${ }_{(12-41)}$ for intracranial injections, because the R121919 solution clogged the 22 gauge injectors, and therefore we could not inject the CRF1 receptor antagonist into the BNST.

\section{Intracranial surgery and injections}

Rats were anesthetized by intramuscular injections of tiletamine chlorahydrate $(200 \mathrm{mg} / \mathrm{kg})$ and zolazepam chlorahydrate $(200 \mathrm{mg} / \mathrm{kg}$; Virbac); the rats were also given a prophylactic dose of rubrocillin $(200 \mu \mathrm{l} / \mathrm{rat}$; Farmaceutici Gellini Spa) to prevent postsurgery infections. For BNST injections, bilateral cannulas (22 gauge; Unimed) were stereotaxically implanted and cemented to the skull with jeweler's screws and dental cement. The Paxinos and Watson (2005) coordinates were as follows: anteroposterior (AP), $-0.3 \mathrm{~mm}$ from bregma; mediolateral (ML), 1.4 $\mathrm{mm}$ from the sagittal suture; and dorsoventral (DV), $6.0 \mathrm{~mm}$ from the skull surface (Nijsen et al., 2001; Ciccocioppo et al., 2003; Fendt et al., 2005; Lungwitz et al., 2012). For ventricular injections, a single cannula was implanted into one of the lateral ventricles. The Paxinos and Watson (2005) coordinates were as follows: AP, $-1.0 \mathrm{~mm}$ from bregma; ML, 1.8 $\mathrm{mm}$ from the sagittal suture; and DV, $2.0 \mathrm{~mm}$ from the skull surface. A stainless-steel blocker the same length of the cannula was placed into the guide cannula at the end of surgery. To verify accurate cannula placement in the ventricles, the rats received an intracerebroventricular injection of $100 \mathrm{ng} / \mathrm{rat}$ angiotensin II (Johnson and Epstein, 1975); only rats that showed a clear dipsogenic response (at least $6 \mathrm{ml}$ of water in $5 \mathrm{~min}$ ) were used in the experiments ( 4 of the 72 rats were excluded).

BNST or ventricular injections of D-Phe- $\mathrm{CRF}_{(12-41)}$ or its vehicle were made with Harvard infusion pumps, using $10 \mu \mathrm{l}$ Hamilton syringes connected to the injectors (Unimed) via polyethylene-10 tubing; the tip of the injector was $1.2 \mathrm{~mm}$ (for BNST) or $2.5 \mathrm{~mm}$ (for lateral ventricle) below the end of the guide cannulas. Injections lasted $1 \mathrm{~min}$, and injectors were left in place for 1 additional minute before being replaced with cannula blockers. At the end of the experiments, the rats were deeply anesthetized and decapitated, and their brains were removed, snap frozen in $-40^{\circ} \mathrm{C}$ isopentane, and stored at $-80^{\circ} \mathrm{C}$. Subsequently, the brains were sliced into coronal sections $(30 \mu \mathrm{m})$ and stained with cresyl violet. The sections were then examined for cannula placements under a microscope. After histology, we excluded 12 of the 80 rats from the analysis because of placements outside the dorsal or ventral BNST.

\section{Fos immunohistochemistry}

The Fos-immunoreactive (IR) procedure is based on our previous studies (Bossert et al., 2011, 2012; Nair et al., 2011; Cifani et al., 2012). Ninety minutes after the start of the frustration stress manipulation or no stress, the rats were deeply anesthetized with isoflurane $(80 \mathrm{~s})$ and perfused transcardially with $100 \mathrm{ml}$ of $0.1 \mathrm{M}$ PBS, followed by $400 \mathrm{ml}$ of $4 \%$ paraformaldehyde in $0.1 \mathrm{~m}$ sodium phosphate, $\mathrm{pH}$ 7.4. The brains were removed, postfixed in $4 \%$ paraformaldehyde for $2 \mathrm{~h}$, and transferred to $30 \%$ sucrose in $0.1 \mathrm{M}$ sodium phosphate, $\mathrm{pH} 7.4$, for $48 \mathrm{~h}$ at $4^{\circ} \mathrm{C}$.

The brains were subsequently frozen in powdered dry ice and stored at $-80^{\circ} \mathrm{C}$ until sectioning. Coronal sections of $40 \mu \mathrm{m}$ thickness, $\sim 0.26 \mathrm{~mm}$ posterior from bregma (Paxinos and Watson, 2005), containing the ventral and dorsal BNST were cut on a cryostat (Leica), collected in cryopro- 
tectant $(20 \%$ glycerol and $2 \%$ dimethylsulfoxide in $0.1 \mathrm{~m}$ sodium phosphate, $\mathrm{pH} 7.4$ ), and stored at $-80^{\circ} \mathrm{C}$ until additional processing. Free-floating sections were washed (three times for $10 \mathrm{~min}$ each) in PBS, incubated for $1 \mathrm{~h}$ in blocking buffer 3\% normal goat serum (NGS) in PBS with $0.25 \%$ Triton $\mathrm{X}-100$ (PBS-Tx), and incubated overnight at $4^{\circ} \mathrm{C}$ with the anti-c-Fos primary antibody (c-Fos sc-52, Lot F2209; Santa Cruz Biotechnology) diluted 1:4000 in blocking buffer.

The sc-52 antibody was raised against amino acids 3-16 of human c-Fos: SGFNADYEASSSRC. Sections were then washed in PBS and incubated for $2 \mathrm{~h}$ with the biotinylated anti-rabbit IgG secondary antibody (BA-1000; Vector Laboratories) diluted 1:600 in 1\% NGS in PBS-Tx. Sections were washed in PBS and incubated in avidin-biotin-peroxidase complex (ABC Elite kit, PK-6100; Vector Laboratories) in PBS containing $0.5 \%$ Triton $\mathrm{X}-100$ for $1 \mathrm{~h}$ and washed in PBS.

Sections were developed in 3,30-diaminobenzidine for $4 \mathrm{~min}$, washed in PBS, mounted onto chrome-alum/gelatin-coated slides, and air dried. The slides were dehydrated through a graded series of alcohol $(30,60,90$, 95, 100, and 100\% ethanol), cleared with Citrasolv (Thermo Fisher Scientific), and coverslipped with Permount (Sigma). Bright-field images of the BNST were digitally captured using a CCD Camera (Photometrics Coolsnap; Roper Scientific) attached to a Zeiss Axioskop 2 microscope using a $10 \times$ objective. Labeled Fos-IR nuclei from one to two sections from the left and right hemispheres of each rat under different experimental conditions were automatically counted using IPLab software (version 3.9.4 r5; Scanalytics) for Macintosh. Image capture and quantification of Fos-positive nuclei were conducted in a blind manner (by C.C.).

\section{Binge-eating experimental procedure}

In the experiments described below, different groups of female rats were exposed (or not exposed) for 24 day to three 8-day cycles of food restriction $(66 \%$ of chow intake on days $1-4$ and free feeding on days $5-8$ of each cycle) during which they were given access to palatable food for $2 \mathrm{~h}$ during the light cycle between 10:00 A.M. and 12:00 P.M. ( $2 \mathrm{~h}$ after the onset of the light cycle) on days 5-6 and 13-14 of the first two cycles (total of four exposures). On the binge intake test day, we assessed palatable food intake for $2 \mathrm{~h}$ immediately after exposure to frustration stress (Cifani et al., 2009). The stress manipulation consisted of 15 min exposure to the coffee cup containing the palatable food that was placed inside a metallic grid container and hung up on the anterior wall of the cage. The rats could see and smell the palatable food but could not access it. During this $15 \mathrm{~min}$ period, the rats engaged in repeated movements of the forepaws, head, and trunk, suggesting that they were attempting to reach the palatable food. The rats were exposed (or not exposed) to the stress manipulation between 10:00 A.M. and 12:00 P.M. After $15 \mathrm{~min}$, the palatable food cup was placed inside the cage, and food intake was determined for $2 \mathrm{~h}$. During the test session, we measured food intake 15, 30, 60 , and $120 \mathrm{~min}$ after frustration stress or no stress exposure.

Immediately after testing, we collected vaginal smears and analyzed them under a microscope to assess the ovarian phase. We determined the estrous cycle phase in a blind manner to the experimental conditions. We found previously that stress-induced binge eating in our model is not observed during the estrous phase (Micioni Di Bonaventura et al., 2010). Therefore, we excluded rats that were in this phase from the experiments (a total of 66 of the 296 rats used in the experiments were excluded for this reason). Palatable food intake at $15 \mathrm{~min}$ and $2 \mathrm{~h}$ of the vehicleinjected rats that were in estrous in the restriction plus stress condition across Experiments 1 and 3 was $47.6 \pm 5.5$ and $95.2 \pm 3.2 \mathrm{kcal} / \mathrm{kg}$, respectively $(n=5)$. These values were significantly lower ( $p$ values $<0.05$ ) than those of vehicle-injected rats that were not in estrous in the restriction plus stress condition in Experiment 1 (135.2 \pm 4.3 and $158.0 \pm 10.5$, respectively, $n=7$ ), Experiment 3 BNST injections (138.5 \pm 8.6 and $167.7 \pm 7.8$, respectively, $n=8)$, and Experiment 3 intracerebroventricular injections $(120.1 \pm 6.2$ and $145.9 \pm 10.4$, respectively, $n=7)$.

Experiment 1: effect of the CRF-1 receptor antagonist $R 121919$ on stress-induced binge eating

In Experiment 1, we determined the effect of systemic injections of R121919 on frustration stress-induced binge-like eating in our model.
We used 108 rats that we divided into 12 groups ( $n=9$ per group) in a 2 (history of intermittent food restriction: no, yes) $\times 2$ (stress during testing: no, yes) $\times 3$ (R121919 dose: 0, 10, $20 \mathrm{mg} / \mathrm{kg}$ ) factorial design. We exposed the rats to three consecutive 8 -d cycles of intermittent food restriction or no restriction during which we also gave them access or no access to the palatable food for $2 \mathrm{~h} / \mathrm{d}$ on days 5, 6, 13, and 14 (see above). Subsequently, on day 25, we exposed or did not expose the rats to $15 \mathrm{~min}$ of frustration stress immediately before the $2 \mathrm{~h}$ palatable food consumption test. We injected the rats with vehicle or R121919 60 min before the $2 \mathrm{~h}$ palatable food access.

\section{Experiment 2: effect of frustration stress on Fos expression in BNST}

In Experiment 2, we determined whether frustration stress increases Fos expression in ventral and dorsal BNST. We used 36 rats ( $n=9$ per group) in a 2 (history of intermittent food restriction: no, yes) $\times 2$ (frustration stress during testing: no, yes) factorial design. We exposed or did not expose the rats to 3 consecutive 8 - $d$ cycles of intermittent food restriction during which we also gave them access to the palatable food for $2 \mathrm{~h} / \mathrm{d}$ on days 5, 6, 13, and 14 (see above). On day 25, we exposed or did not expose the rats to the $15 \mathrm{~min}$ frustration stress manipulation and extracted their brains (after anesthesia and perfusion) 90 min later for subsequent Fos immunohistochemistry assays. We did not assess binge eating in these groups, because we wanted to assess the "pure" effect of the stress manipulation of BNST neuronal activity without the potential impact of food intake during testing on neuronal activity.

\section{Experiment 3: effect of BNST and ventricular injections of}

$D$-Phe-CRF ${ }_{(12-41)}$ on stress-induced binge eating

In Experiment 3, we determined the effect of BNST and ventricular injections of the nonselective CRF receptor antagonist D-Phe-CRF ${ }_{(12-41)}$ on stress-induced binge-like eating in our model.

BNST injections. We used 80 rats that were divided into eight groups ( $n=10$ per group). Four groups were not exposed to cycles of food restriction or frustration stress and were tested for the effect of D-Phe$\mathrm{CRF}_{(12-41)}$ injections $(0,10,25$, and $50 \mathrm{ng} /$ side $)$ on palatable food intake during the $2 \mathrm{~h}$ test on day 25 . Four other groups were exposed to three cycles of food restriction and frustration stress and were tested for the effect of D-Phe-CRF ${ }_{(12-41)}$ injections $(0,10,25$, and $50 \mathrm{ng} /$ side $)$ on stressinduced palatable food intake during the $2 \mathrm{~h}$ test on day 25 . We injected D-Phe-CRF $\mathrm{C}_{(12-41)} 30 \mathrm{~min}$ before the $2 \mathrm{~h}$ palatable food access $(15 \mathrm{~min}$ before the beginning of the frustration stress for the stress groups).

Ventricular injections. We used 72 rats that we divided into eight groups ( $n=9$ per group). Four groups were not exposed to cycles of food restriction or frustration stress and were tested for the effect of D-Phe$\mathrm{CRF}_{(12-41)}$ injections $(0,100,300$, and $1000 \mathrm{ng})$ on palatable food intake during the $2 \mathrm{~h}$ test on day 25 . Four other groups were exposed to three cycles of food restriction and frustration stress and were tested for the effect of D-Phe-CRF ${ }_{(12-41)}$ injections $(0,100,300$, and $1000 \mathrm{ng})$ on stressinduced palatable food intake during the $2 \mathrm{~h}$ test on day 25 . We injected D-Phe-CRF ${ }_{(12-41)} 30 \mathrm{~min}$ before the $2 \mathrm{~h}$ palatable food access (15 min before the beginning of the frustration stress for the stress group).

\section{Statistical analysis}

We report the results as mean \pm SEM. We analyzed the data with factorial ANOVAs using the factors described in Results. We used Bonferroni's post hoc tests to follow up on significant interaction or main effects $(p<0.05)$ from the factorial ANOVAs. We analyzed the data with Systat version 10.0 (Systat Software).

\section{Results}

\section{Effect of the CRF1 receptor antagonist R121919 on} stress-induced binge eating

Body weight (days 1-24)

In Figure $1 A$, we show the timeline of the experimental procedure, and in Figure $1 B$, we show body weight fluctuations during the three 8-day cycles during which we either exposed or did not expose the rats to food restriction on days $1-4$ of each cycle $(66 \%$ of regular chow availability). As in our previous studies (Cifani et 


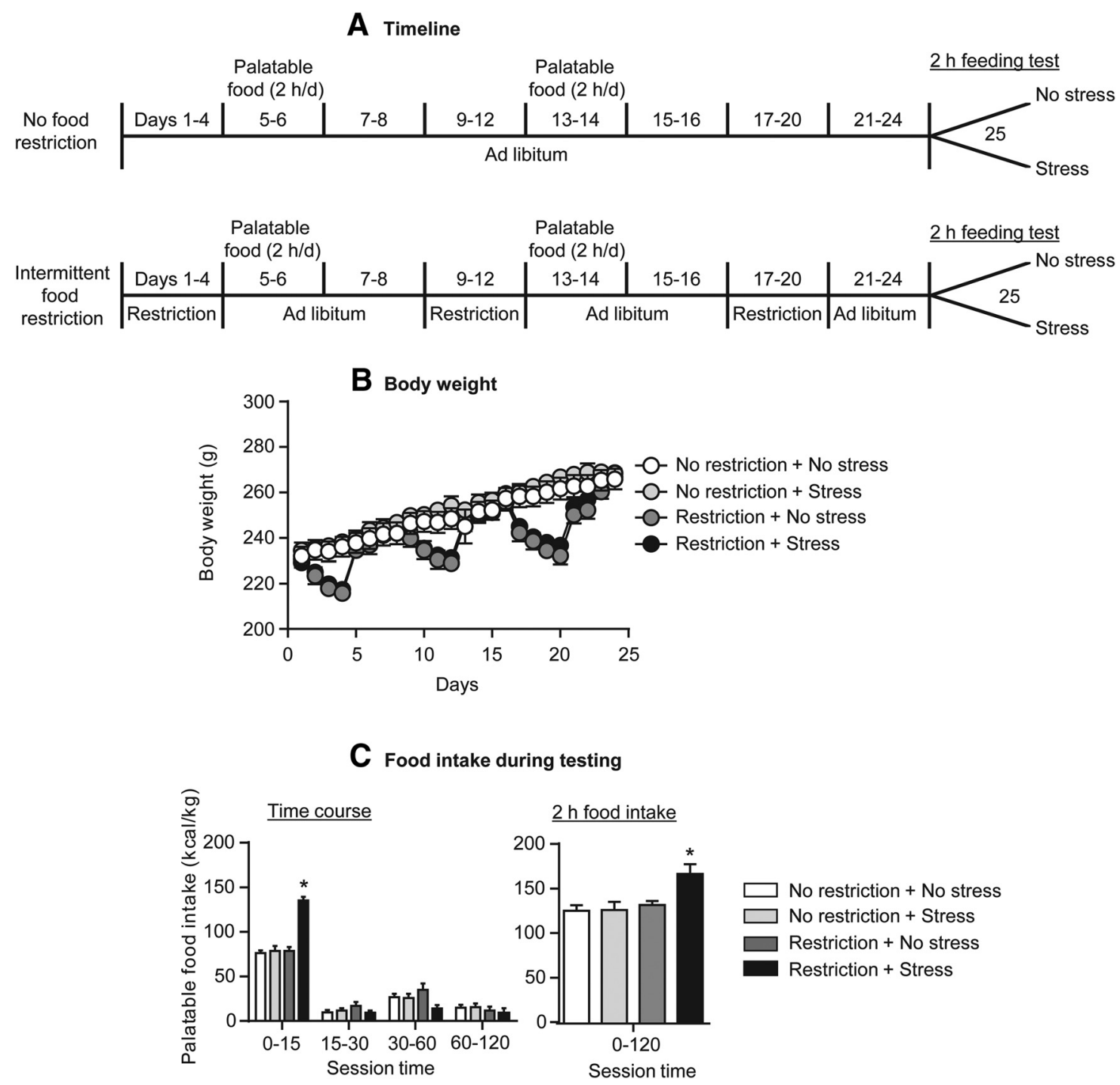

Figure 1. Increased palatable food intake in rats with a history of intermittent food restriction that were exposed to frustration stress before the feeding test. $A$, Timeline of the experimental procedures for the food nonrestricted (top) and restricted (bottom) rats. B, Mean \pm SEM body weight (grams) of female rats exposed or not exposed to repeated intermittent cycles of food restriction/refeeding. C, Mean \pm SEM palatable food intake at different time points during testing (left) and total $2 \mathrm{~h}$ food intake (right) in the vehicle-injected rats in Experiment $1 .{ }^{*} p<$ 0.05 , different from the other three groups; $n=6-8$ per group.

al., 2009, 2010), we found that the rats lost weight during the 4-day food restriction period and regained it during the subsequent 4-day free-food period. On the test day (day 25) of Experiment 1 and the other experiments (data not shown), the body weight of the rats in the restricted and nonrestricted groups was not significantly different.

Palatable food test (day 25, vehicle group)

We found that, in rats with a history of intermittent food restriction, exposure to $15 \mathrm{~min}$ frustration stress increased palatable food consumption during the first $15 \mathrm{~min}$ of the feeding test on day 25; this stress manipulation had no effect on food intake in rats that were not food restricted during the first 24 days of the experiment. During the remaining time of the $2 \mathrm{~h}$ test (minutes 15-120), no compensatory changes in palatable food consumption were observed (Fig. 2C). The statistical analysis, which included the between-subjects factors of history of intermittent food restriction (no, yes) and frustration stress during testing (no, yes), and the within-subject factor of session time (0-15, $15-30,30-60,60-120 \mathrm{~min}$ ) showed a significant interaction be- tween the three factors $\left(F_{(3,72)}=16.7, p<0.01\right)$. Post hoc tests confirmed a significant $(p<0.05)$ increase in food consumption only at the $0-15$ min time point and only in rats with a history of food restriction, followed by frustration stress. These data are in agreement with our previous studies on the effect of our experimental manipulations on binge-like eating in our rat model (Cifani et al., 2009, 2010; Micioni Di Bonaventura et al., 2012; Piccoli et al., 2012).

\section{Effect of R121919}

We found that systemic injections of R121919 in rats with a history of intermittent food restriction decreased frustration stressinduced increases in palatable food consumption during testing on day 25 (Fig. 2A). In contrast, R121919 injections had no effect on palatable food intake in the no-stress groups independent of the feeding conditions (restriction, no restriction) during the first $24 \mathrm{~d}$ or in rats exposed to stress during testing but had no previous experience with food restriction. The statistical analysis, which included the between-subjects factors of history of intermittent food restriction (no, yes), stress during testing (no, yes), and 
$15 \min$ food intake

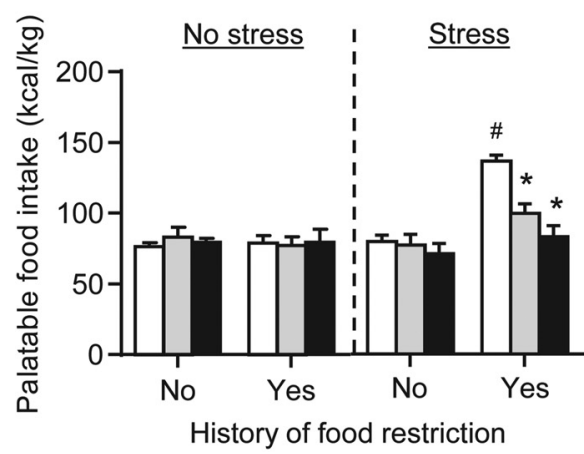

$2 \mathrm{~h}$ food intake

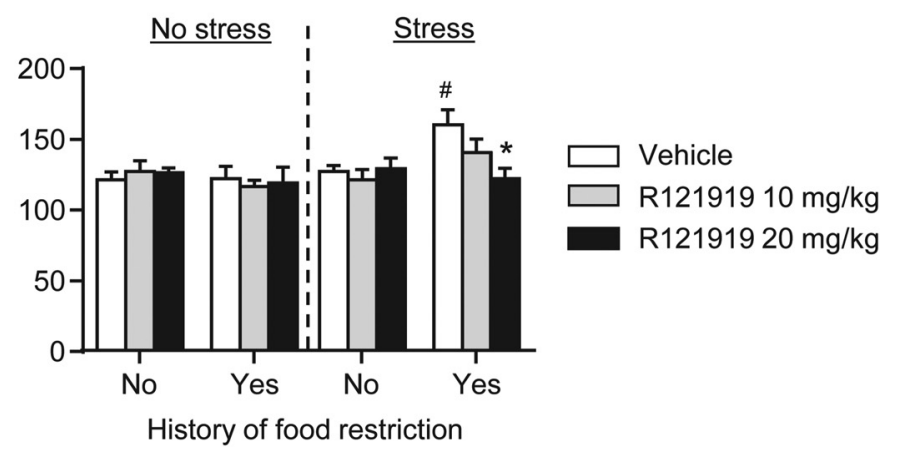

Figure 2. Systemic injections of the CRF1 receptor antagonist R121919 decreased frustration stress-induced binge eating in rats with a history of intermittent food restriction. Mean \pm SEM palatable food intake (kilocalories per kilogram) during the first $15 \mathrm{~min}$ (left) and the total $2 \mathrm{~h}$ (right) test session. The rats were injected with R121919 (0, 10 , or $20 \mathrm{mg} / \mathrm{kg}$, s.c.) $60 \mathrm{~min}$ before the start of the test session and exposed or not exposed to $15 \mathrm{~min}$ frustration stress before the test session. ${ }^{*} p<0.05$, different from the vehicle condition; $n=6-8$ per group. ${ }^{*} p<0.05$, different from the other three vehicle groups.

$\mathrm{R} 121919$ dose $(0,10,20 \mathrm{mg} / \mathrm{kg})$, and the within-subjects factor of session time $(0-15,15-30,30-60,60-120 \mathrm{~min})$, showed a significant interaction between the four factors $\left(F_{(6,213)}=4.0, p<\right.$ 0.01 ). Subsequent two-way ANOVAs within each group showed a significant interaction of R121919 dose with session time in the intermittent food restriction plus frustration stress group $\left(F_{(2,20)}=4.29, p<0.05\right)$ but not in the other groups ( $p$ values $>0.1)$. Post hoc group differences are indicated in Figure 2 .

\section{Experiment 2: effect of frustration stress on Fos expression in BNST}

We found that, in rats with a history of intermittent food restriction on days 1-24, exposure to $15 \mathrm{~min}$ of frustration stress on day 25 increased Fos immunoreactivity in both dorsal and ventral BNST (Fig. $3 B, C$ ). The statistical analysis, which included the between-subjects factors of history of intermittent food restriction (no, yes) and stress during testing (no, yes), and the withinsubjects factor of BNST region (dorsal, ventral), showed a significant interaction between intermittent food restriction history and stress during testing $\left(F_{(1,22)}=19.0, p<0.01\right)$. Post hoc group differences are indicated in Figure 3.

\section{Experiment 3: effect of BNST and ventricular injections of D-Phe-CRF ${ }_{(12-41)}$ on stress-induced binge eating}

In rats with a history of intermittent food restriction, BNST injections of low D-Phe-CRF ${ }_{(12-41)}$ doses (25 and $50 \mathrm{ng}$ ) and ventricular injections of a significantly higher dose of the drug (1000 ng) decreased frustration stress-induced palatable food intake during the first 15 min of testing (Fig. $4 A, B$ ). BNST or ventricular injections of D-Phe-CRF $\mathrm{C}_{(12-41)}$ had no effect on palatable food consumption in rats that were not exposed to food restriction and frustration stress.

\section{BNST injections}

The statistical analysis, which included the between-subjects factors of group condition (no food restriction plus no stress, food restriction plus stress) and D-Phe- $\mathrm{CRF}_{(12-41)}$ dose $(0,10,25,50$ $\mathrm{ng} /$ side), and the within-subjects factor of session time $(0-15$, 15-30, 30-60, 60-120 min), showed a significant interaction between the three factors $\left(F_{(9,132)}=6.7, p<0.01\right)$. Post hoc group differences are indicated in Figure 4.

\section{Ventricular injections}

The statistical analysis, which included the between-subjects factors of group condition (no food restriction plus no stress, food restriction plus stress) and D-Phe-CRF $\mathrm{C}_{(12-41)}$ dose $(0,100,300$, $1000 \mathrm{ng}$ ), and the within-subjects factor of session time, showed a significant interaction between the three factors $\left(F_{(9,135)}=2.2\right.$, $p<0.05)$. Post hoc group differences and the time course of food intake during testing are indicated in Figure 4.

\section{Discussion}

As in our previous reports (Cifani et al., 2009, 2010), we found that exposure to frustration stress selectively induced binge-like palatable food eating during the first $15 \mathrm{~min}$ of the test session in female rats with a history of repeated cycles of food restriction. More importantly, we found that systemic injections of the CRF1 receptor antagonist R121919 and BNST or ventricular injections of the nonselective CRF receptor antagonist D-Phe-CRF $\mathrm{C}_{(12-41)}$ selectively blocked frustration stress-induced binge eating after a history of food restriction. The effective D-Phe-CRF $\mathrm{C}_{(12-41)}$ dose for ventricular injections (1000 ng) was substantially higher than the effective doses for BNST injections (25-50 ng/side). Additionally, a history of food restriction plus frustration stress induced a selective increase in Fos immunoreactivity in ventral and dorsal BNST. Together, these data indicate a critical role of BNST CRF systems in frustration stress-induced binge eating. Additionally, the observation that blockade of CRF receptors in the BNST completely reversed stress-induced binge eating in our model indicates a critical role of extrahypothalamic CRF systems. This conclusion is in agreement with a large body of research indicating that the role of CRF in the behavioral effects of drugs of abuse, including escalation of drug intake, protracted withdrawal symptoms, and stress-induced reinstatement, is attributable to activation of extrahypothalamic CRF systems, independent of the known role of CRF within the HPA axis (Shaham et al., 2000; Heilig and Koob, 2007; Koob, 2008; Shalev et al., 2010; Bruijnzeel, 2012; Mantsch et al., 2014).

Our data extend previous results on the role of CRF1 receptors in binge eating in a different rat model (Cottone et al., 2009). However, in contrast to our findings that implicate BNST CRF receptors in stress-induced binge eating, Iemolo et al. (2013) reported, using their binge-eating model, that the critical site for CRF modulation of binge eating is central amygdala, not BNST. A question for future research is whether 


\section{A Fos-IR BNST quantification}

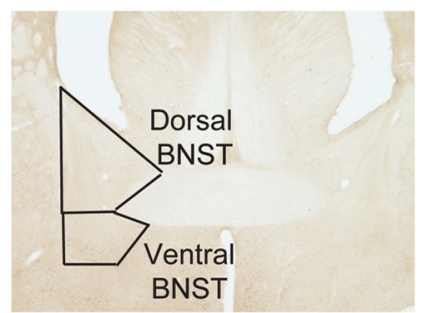

B Fos-IR in dorsal BNST

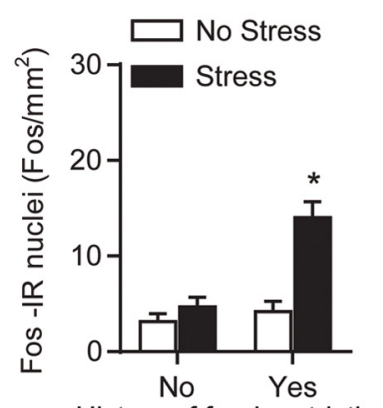

History of food restriction
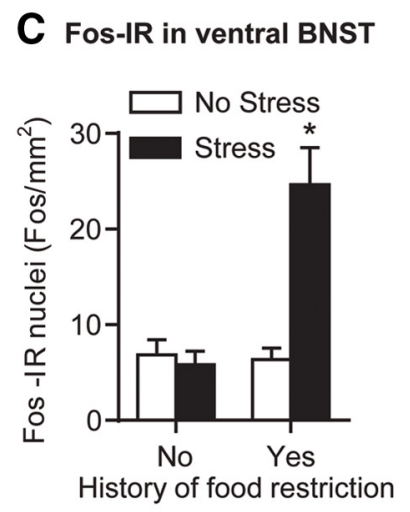

place preferences is the BNST (Erb and Stewart, 1999; Erb et al., 2001; Wang et al., 2006). Finally, our data extend a large body of research on the role of BNST CRF in stress and anxiety responses (Davis et al., 2010; Silberman and Winder, 2013).

One methodological issue to consider is whether the effect of the CRF receptor antagonists on stress-induced binge eating in our model is attributable to nonselective effects on feeding behavior. This possibility is unlikely because, as seen in Figures 2 and 4, the CRF receptor antagonists had no effect on palatable food intake in rats not exposed to frustration stress during testing or rats without a previous history of food restriction regardless of exposure to stress. This pattern of results with the CRF receptor antagonist is different from our previous results in which we found that the selective serotonin reuptake blocker fluoxetine or the mixed serotonin-noradrenaline reuptake blocker sibutramine decreased both stressinduced binge eating and palatable food intake without stress exposure (Cifani et al., 2009). Our data are in agreement with a recent report of Parylak et al. (2012), which showed that systemic injections of R121919 had no effect on binge-like eating in female rats not exposed to stress in a different binge-eating model.

Another methodological issue to consider is that the effect of D-Phe-CRF $(12-41)$ BNST injections on stress-induced binge eating might be attributable to ventricular diffusion and consequently an effect of the drug in distal brain areas (Johnson and Epstein, 1975; Wise and Hoffman, 1992). The BNST is in very close proximity to the lateral ventricle (Fig. 4C). Additionally, after central drug injections, the drug invariably diffuses dorsal to the injection site because of a pressure gradient (Wise and Hoffman, 1992). Therefore, it is highly likely that, after our BNST injections, D-Phe-CRF ${ }_{(12-41)}$ reached the ventricles. However, it is unlikely that the effect of D-Phe-CRF ${ }_{(12-41)}$ BNST injections on palatable food intake is attributable to ventricular diffusion. As can been seen in Figure $4 B$, a dose of D-Phe- $\mathrm{CRF}_{(12-}$ 41) $(300 \mathrm{ng} / \mathrm{rat})$, which is higher than our effective BNST doses ( 25 and $50 \mathrm{ng} /$ side or 50 and $100 \mathrm{ng} / \mathrm{rat}$ ) was ineffective. Addi-

the central amygdala plays a role in stress-induced binge eating in our rat model. Our data also extend previous reports on the effect of systemic injections of CRF1 receptor antagonists on stress-induced reinstatement of drug and food seeking (Shaham et al., 1998; Lê et al., 2000; Ghitza et al., 2006; Hansson et al., 2006; Bruijnzeel et al., 2009; McReynolds et al., 2014). Additionally, a critical site for CRF modulation of stress-induced reinstatement of drug seeking or conditioned tionally, even the highest ventricular dose (1000 ng/rat) was somewhat less effective than the highest BNST dose (100 ng/rat; see $2 \mathrm{~h}$ food intake data in Fig. $4 A, B$ ).

Another issue to consider is the CRF receptor type that mediates the effect of BNST D-Phe- $\mathrm{CRF}_{(12-41)}$ injections on stressinduced binge eating in our model. D-Phe-CRF $\mathrm{C}_{(12-41)}$ is a nonselective CRF receptor antagonist (Menzaghi et al., 1994) that 
binds to both the CRF1 and CRF2 receptor subtypes (Behan et al., 1996). However, we suspect that BNST D-Phe$\mathrm{CRF}_{(12-41)}$ injections likely decreased stress-induced binge eating because of the action of the drug on CRF1 receptors. This is because CRF1 expression in the different divisions of the BNST is higher than CRF2 expression (Van Pett et al., 2000). Additionally, we found that BNST injections of D-Phe- $\mathrm{CRF}_{(12-41)}$ mimicked the effect of systemic injections of the selective CRF1 receptor R121919 on stressinduced binge eating. However, in the absence of additional studies on the effect of a selective CRF2 receptor antagonist, such as astressin $_{2}$-B (Zorrilla et al., 2013a), or gene knockdown of the CRF2 receptor (Lebow et al., 2012), it cannot be concluded conclusively that BNST CRF1 receptors mediate stress-induced binge eating in our model.

In conclusion, we demonstrated that systemic injections of R121919, a smallmolecule CRF1 receptor antagonist that readily crosses the blood-brain barrier (Heinrichs et al., 2002), blocked frustration stress-induced binge eating without affecting food intake without stress exposure. We have also identified a key role of CRF receptors in BNST in frustration stress-induced binge eating after a history of food restriction and demonstrated that neurons in both ventral and dorsal BNST are selectively activated, as assessed by Fos immunoreactivity, by the frustration stress manipulation. Our positive injection sites were located in both the ventral and dorsal BNST (Fig. 4C). The two BNST subregions are known to have different afferent and efferent projections and to play a role in different physiological and behavioral functions (Ju et al., 1989; AstonJones et al., 1999; Cassell et al., 1999; Davis et al., 2010; Crestani et al., 2013). Thus, a question for future research is whether CRF transmission in ventral and dorsal BNST plays distinct or similar roles in stress-induced binge eating in our model.

Finally, to the degree that our rat model is relevant to the human condition, our results may have clinical implications for the treatment of stress-related bingeeating disorders. Over the past decade, a number of CRF1 receptor antagonists have passed toxicity screening and were tested in clinical trials for their efficacy in the treatment of anxiety and depression (Holsboer and Ising, 2008; Zorrilla and Koob, 2010); CRF1 receptor antagonists are also currently being considered for potential pharmacological treatment of drug

\section{A BNST injections}

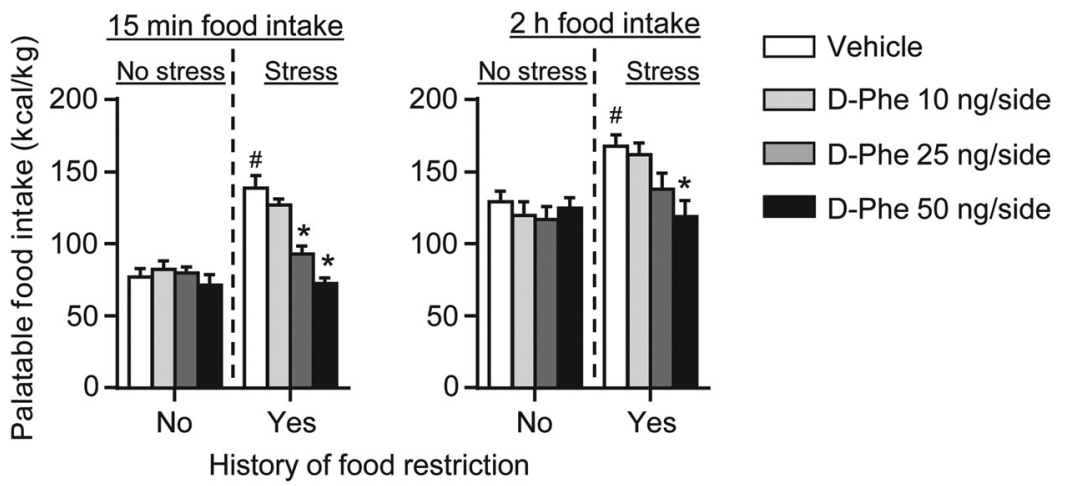

B Lateral ventricle injections

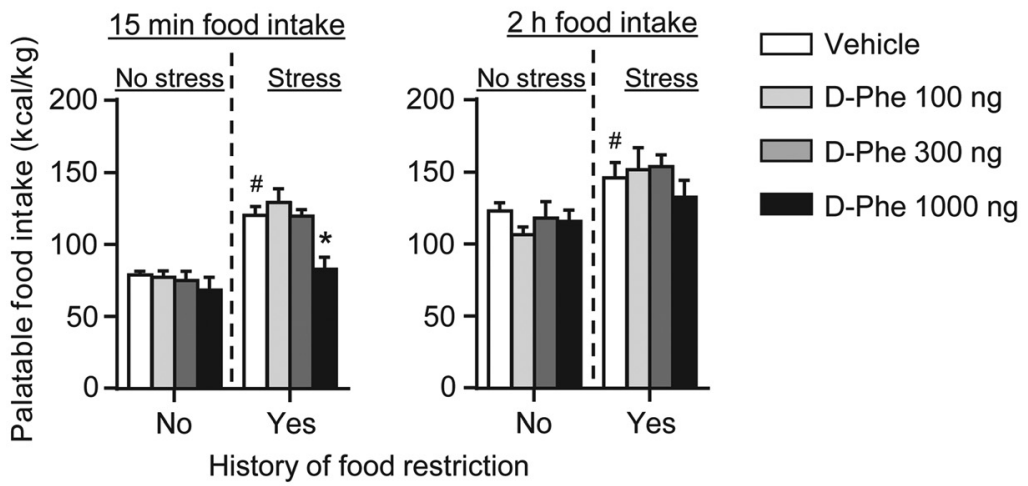

\section{Cannula placements in BNST}

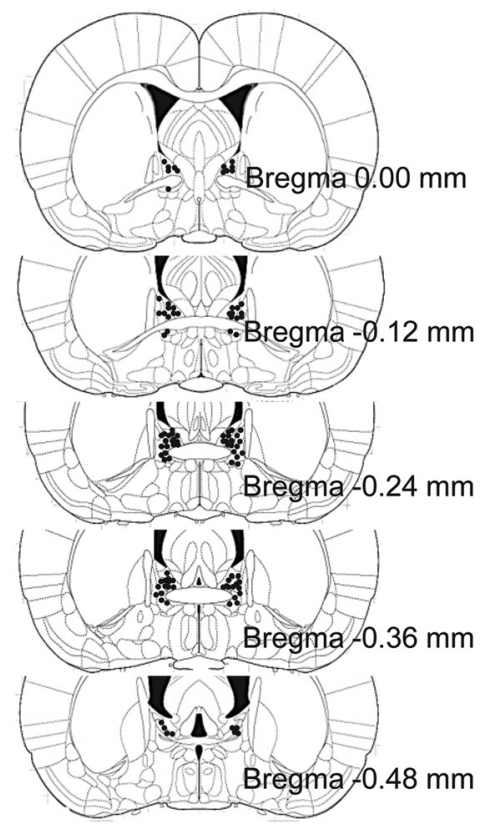

Figure 4. BNST and ventricular injections of the CRF receptor antagonist D-Phe-CRF ${ }_{(12-41)}$ decreased frustration stress-induced binge eating in rats with a history of intermittent food restriction. $A$, BNST injections. Mean \pm SEM palatable food intake (kilocalories per kilogram) during the first $15 \mathrm{~min}$ (left) and the total $2 \mathrm{~h}$ (right) test session. ${ }^{*} p<0.05$, different from the vehicle condition; $n=6-8$ per group. ${ }^{\#} p<0.05$, different from the vehicle no restriction plus no stress group. $\boldsymbol{B}$, Lateral ventricle injections. Mean \pm SEM palatable food intake (kilocalories per kilogram) during the first $15 \mathrm{~min}$ (left) and the total $2 \mathrm{~h}$ (right) test session. ${ }^{*} p<0.05$, different from the vehicle condition; $n=6-8$ per group. ${ }^{\#} p<0.05$, different from the vehicle no restriction plus no stress group. C, Approximate placements (millimeters from bregma) of injector tips in BNST of the 52 rats included in the statistical analysis (Paxinos and Watson, 2005). 
addiction (Sinha et al., 2011; Zorrilla et al., 2013b). Evidence for the efficacy of CRF1 receptor antagonists in psychiatric disorders has not yet been documented, and several clinical trials for depression and anxiety reported negative results (Zorrilla and Koob, 2010; Zorrilla et al., 2013b). Against this background, our data and those of Cottone, Sabino, and colleagues (Cottone et al., 2009; Iemolo et al., 2013) suggest a potential novel use of CRF1 receptor antagonists in the treatment of stress-related bingeeating disorders.

\section{References}

American Psychiatric Association (2013) Diagnostic and statistical manual of mental disorders, Ed 4. Washington, DC: American Psychiatric Association.

Amsel A (1958) The role of frustrative nonreward in noncontinuous reward situations. Psychol Bull 55:102-119. CrossRef Medline

Aston-Jones G, Delfs JM, Druhan J, Zhu Y (1999) The bed nucleus of the stria terminalis: a target site for noradrenergic actions in opiate withdrawal. Ann N Y Acad Sci 877:486-498. CrossRef Medline

Avena NM, Rada P, Hoebel BG (2008) Evidence for sugar addiction: behavioral and neurochemical effects of intermittent, excessive sugar intake. Neurosci Biobehav Rev 32:20-39. CrossRef Medline

Bale TL, Vale WW (2004) CRF and CRF receptors: role in stress responsivity and other behaviors. Annu Rev Pharmacol Toxicol 44:525-557. CrossRef Medline

Behan DP, Grigoriadis DE, Lovenberg T, Chalmers D, Heinrichs S, Liaw C, De Souza EB (1996) Neurobiology of corticotropin releasing factor (CRF) receptors and CRF-binding protein: implications for the treatment of CNS disorders. Mol Psychiatry 1:265-277. Medline

Bossert JM, Stern AL, Theberge FR, Cifani C, Koya E, Hope BT, Shaham Y (2011) Ventral medial prefrontal cortex neuronal ensembles mediate context-induced relapse to heroin. Nat Neurosci 14:420-422. CrossRef Medline

Bossert JM, Stern AL, Theberge FR, Marchant NJ, Wang HL, Morales M, Shaham Y (2012) Role of projections from ventral medial prefrontal cortex to nucleus accumbens shell in context-induced reinstatement of heroin seeking. J Neurosci 32:4982-4991. CrossRef Medline

Bossert JM, Marchant NJ, Calu DJ, Shaham Y (2013) The reinstatement model of drug relapse: recent neurobiological findings, emerging research topics, and translational research. Psychopharmacology 229:453-476. CrossRef Medline

Bruijnzeel AW (2012) Tobacco addiction and the dysregulation of brain stress systems. Neurosci Biobehav Rev 36:1418-1441. CrossRef Medline

Bruijnzeel AW, Prado M, Isaac S (2009) Corticotropin-releasing factor-1 receptor activation mediates nicotine withdrawal-induced deficit in brain reward function and stress-induced relapse. Biol Psychiatry 66:110-117. CrossRef Medline

Cassell MD, Freedman LJ, Shi C (1999) The intrinsic organization of the central extended amygdala. Ann N Y Acad Sci 877:217-241. CrossRef Medline

Ciccocioppo R, Fedeli A, Economidou D, Policani F, Weiss F, Massi M (2003) The bed nucleus is a neuroanatomical substrate for the anorectic effect of corticotropin-releasing factor and for its reversal by nociceptin/ orphanin FQ. J Neurosci 23:9445-9451. Medline

Cifani C, Polidori C, Melotto S, Ciccocioppo R, Massi M (2009) A preclinical model of binge eating elicited by yo-yo dieting and stressful exposure to food: effect of sibutramine, fluoxetine, topiramate, and midazolam. Psychopharmacology 204:113-125. CrossRef Medline

Cifani C, Micioni Di B MV, Vitale G, Ruggieri V, Ciccocioppo R, Massi M (2010) Effect of salidroside, active principle of Rhodiola rosea extract, on binge eating. Physiol Behav 101:555-562. CrossRef Medline

Cifani C, Koya E, Navarre BM, Calu DJ, Baumann MH, Marchant NJ, Liu QR, Khuc T, Pickel J, Lupica CR, Shaham Y, Hope BT (2012) Medial prefrontal cortex neuronal activation and synaptic alterations after stressinduced reinstatement of palatable food seeking: a study using c-fos-GFP transgenic female rats. J Neurosci 32:8480-8490. CrossRef Medline

Coe CL, Stanton ME, Levine S (1983) Adrenal responses to reinforcement and extinction: role of expectancy versus instrumental responding. Behav Neurosci 97:654-657. CrossRef Medline

Corwin RL, Buda-Levin A (2004) Behavioral models of binge-type eating. Physiol Behav 82:123-130. CrossRef Medline
Cottone P, Sabino V, Steardo L, Zorrilla EP (2008) Opioid-dependent anticipatory negative contrast and binge-like eating in rats with limited access to highly preferred food. Neuropsychopharmacology 33:524-535. CrossRef Medline

Cottone P, Sabino V, Roberto M, Bajo M, Pockros L, Frihauf JB, Fekete EM, Steardo L, Rice KC, Grigoriadis DE, Conti B, Koob GF, Zorrilla EP (2009) CRF system recruitment mediates dark side of compulsive eating. Proc Natl Acad Sci U S A 106:20016-20020. CrossRef Medline

Coutinho WF, Moreira RO, Spagnol C, Appolinario JC (2007) Does binge eating disorder alter cortisol secretion in obese women? Eating Behav 8:59-64. CrossRef Medline

Crestani CC, Alves FH, Gomes FV, Resstel LB, Correa FM, Herman JP (2013) Mechanisms in the bed nucleus of the stria terminalis involved in control of autonomic and neuroendocrine functions: a review. Curr Neuropharmacol 11:141-159. CrossRef Medline

Davis M, Walker DL, Miles L, Grillon C (2010) Phasic vs sustained fear in rats and humans: role of the extended amygdala in fear vs anxiety. Neuropsychopharmacology 35:105-135. CrossRef Medline

Epel E, Lapidus R, McEwen B, Brownell K (2001) Stress may add bite to appetite in women: a laboratory study of stress-induced cortisol and eating behavior. Psychoneuroendocrinology 26:37-49. CrossRef Medline

Erb S, Stewart J (1999) A role for the bed nucleus of the stria terminalis, but not the amygdala, in the effects of corticotropin-releasing factor on stressinduced reinstatement of cocaine seeking. J Neurosci 19:RC35(1-6). Medline

Erb S, Shaham Y, Stewart J (1998) The role of corticotropin-releasing factor and corticosterone in stress- and cocaine-induced relapse to cocaine seeking in rats. J Neurosci 18:5529-5536. Medline

Erb S, Salmaso N, Rodaros D, Stewart J (2001) A role for the CRFcontaining pathway projecting from central nucleus of the amygdala to bed nucleus of the stria terminalis in the stress-induced reinstatement of cocaine seeking in rats. Psychopharmacology 158:360-365. CrossRef Medline

Fendt M, Siegl S, Steiniger-Brach B (2005) Noradrenaline transmission within the ventral bed nucleus of the stria terminalis is critical for fear behavior induced by trimethylthiazoline, a component of fox odor. J Neurosci 25:5998-6004. CrossRef Medline

Funk CK, Zorrilla EP, Lee MJ, Rice KC, Koob GF (2007) Corticotropin-releasing factor 1 antagonists selectively reduce ethanol self-administration in ethanoldependent rats. Biol Psychiatry 61:78-86. CrossRef Medline

Ghitza UE, Gray SM, Epstein DH, Rice KC, Shaham Y (2006) The anxiogenic drug yohimbine reinstates palatable food seeking in a rat relapse model: a role of $\mathrm{CRF}(1)$ receptors. Neuropsychopharmacology 31:2188 2196. CrossRef Medline

Gluck ME, Geliebter A, Lorence M (2004a) Cortisol stress response is positively correlated with central obesity in obese women with binge eating disorder (BED) before and after cognitive-behavioral treatment. Ann N Y Acad Sci 1032:202-207. CrossRef Medline

Gluck ME, Geliebter A, Hung J, Yahav E (2004b) Cortisol, hunger, and desire to binge eat following a cold stress test in obese women with binge eating disorder. Psychosom Med 66:876-881. CrossRef Medline

Hagan MM, Wauford PK, Chandler PC, Jarrett LA, Rybak RJ, Blackburn K (2002) A new animal model of binge eating: key synergistic role of past caloric restriction and stress. Physiol Behav 77:45-54. CrossRef Medline

Hansson AC, Cippitelli A, Sommer WH, Fedeli A, Björk K, Soverchia L, Terasmaa A, Massi M, Heilig M, Ciccocioppo R (2006) Variation at the rat Crhrl locus and sensitivity to relapse into alcohol seeking induced by environmental stress. Proc Natl Acad Sci U S A 103:15236-15241. CrossRef Medline

Heilig M, Koob GF (2007) A key role for corticotropin-releasing factor in alcohol dependence. Trends Neurosci 30:399-406. CrossRef Medline

Heinrichs SC, De Souza EB, Schulteis G, Lapsansky JL, Grigoriadis DE (2002) Brain penetrance, receptor occupancy and antistress in vivo efficacy of a small molecule corticotropin releasing factor type I receptor selective antagonist. Neuropsychopharmacology 27:194-202. CrossRef Medline

Holsboer F, Ising M (2008) Central CRH system in depression and anxiety-evidence from clinical studies with CRH1 receptor antagonists. Eur J Pharmacol 583:350-357. CrossRef Medline

Hudson JI, Hiripi E, Pope HG Jr, Kessler RC (2007) The prevalence and correlates of eating disorders in the National Comorbidity Survey Replication. Biol Psychiatry 61:348-358. CrossRef Medline 
Iemolo A, Blasio A, St Cyr SA, Jiang F, Rice KC, Sabino V, Cottone P (2013) CRF-CRF1 receptor system in the central and basolateral nuclei of the amygdala differentially mediates excessive eating of palatable food. Neuropsychopharmacology 38:2456-2466. CrossRef Medline

Johnson AK, Epstein AN (1975) The cerebral ventricles as the avenue for the dipsogenic action of intracranial angiotensin. Brain Res 86:399-418. CrossRef Medline

Ju G, Swanson LW, Simerly RB (1989) Studies on the cellular architecture of the bed nuclei of the stria terminalis in the rat: II. Chemoarchitecture. J Comp Neurol 280:603-621. CrossRef Medline

Keck ME, Welt T, Wigger A, Renner U, Engelmann M, Holsboer F, Landgraf $\mathrm{R}$ (2001) The anxiolytic effect of the $\mathrm{CRH}(1)$ receptor antagonist R121919 depends on innate emotionality in rats. Eur J Neurosci 13:373380. CrossRef Medline

Kjelsås E, Bjørnstrom C, Götestam KG (2004) Prevalence of eating disorders in female and male adolescents (14-15 years). Eat Behav 5:13-25. CrossRef Medline

Koob GF (2008) A role for brain stress systems in addiction. Neuron 59:1134. CrossRef Medline

Lê AD, Harding S, Juzytsch W, Watchus J, Shalev U, Shaham Y (2000) The role of corticotropin-releasing factor in stress-induced relapse to alcoholseeking behavior in rats. Psychopharmacology 150:317-324. CrossRef Medline

Lê AD, Harding S, Juzytsch W, Fletcher PJ, Shaham Y (2002) The role of corticotropin-releasing factor in the median raphe nucleus in relapse to alcohol. J Neurosci 22:7844-7849. Medline

Lebow M, Neufeld-Cohen A, Kuperman Y, Tsoory M, Gil S, Chen A (2012) Susceptibility to PTSD-like behavior is mediated by corticotropinreleasing factor receptor type 2 levels in the bed nucleus of the stria terminalis. J Neurosci 32:6906-6916. CrossRef Medline

Lungwitz EA, Molosh A, Johnson PL, Harvey BP, Dirks RC, Dietrich A, Minick P, Shekhar A, Truitt WA (2012) Orexin-A induces anxiety-like behavior through interactions with glutamatergic receptors in the bed nucleus of the stria terminalis of rats. Physiol Behav 107:726-732. CrossRef Medline

Mantsch JR, Vranjkovic O, Twining RC, Gasser PJ, McReynolds JR, Blacktop JM (2014) Neurobiological mechanisms that contribute to stressrelated cocaine use. Neuropharmacology 76:383-394. CrossRef Medline

McElroy SL, Shapira NA, Arnold LM, Keck PE, Rosenthal NR, Wu SC, Capece JA, Fazzio L, Hudson JI (2004) Topiramate in the long-term treatment of binge-eating disorder associated with obesity. J Clin Psychiatry 65: 1463-1469. CrossRef Medline

McReynolds JR, Peña DF, Blacktop JM, Mantsch JR (2014) Neurobiological mechanisms underlying relapse to cocaine use: contributions of CRF and noradrenergic systems and regulation by glucocorticoids. Stress 17:22-38. CrossRef Medline

Menzaghi F, Howard RL, Heinrichs SC, Vale W, Rivier J, Koob GF (1994) Characterization of a novel and potent corticotropin-releasing factor antagonist in rats. J Pharmacol Exp Ther 269:564-572. Medline

Micioni Di Bonaventura MV, Cifani C, Ciccocioppo R, Massi M (2010) Influence of the ovarian cycle on binge eating evoked in female rats by stress and food restriction. Appetite 54:663.

Micioni Di Bonaventura MV, Cifani C, Lambertucci C, Volpini R, Cristalli G, Massi M (2012) A(2A) adenosine receptor agonists reduce both highpalatability and low-palatability food intake in female rats. Behav Pharmacol 23:567-574. CrossRef Medline

Morgan JI, Curran T (1991) Stimulus-transcription coupling in the nervous system: involvement of the inducible proto-oncogenes fos and jun. Annu Rev Neurosci 14:421-451. CrossRef Medline

Nair SG, Navarre BM, Cifani C, Pickens CL, Bossert JM, Shaham Y (2011) Role of dorsal medial prefrontal cortex dopamine D1-family receptors in relapse to high-fat food seeking induced by the anxiogenic drug yohimbine. Neuropsychopharmacology 36:497-510. CrossRef Medline
Nijsen MJ, Croiset G, Diamant M, De Wied D, Wiegant VM (2001) CRH signalling in the bed nucleus of the stria terminalis is involved in stressinduced cardiac vagal activation in conscious rats. Neuropsychopharmacology 24:1-10. CrossRef Medline

Parylak SL, Cottone P, Sabino V, Rice KC, Zorrilla EP (2012) Effects of CB1 and CRF1 receptor antagonists on binge-like eating in rats with limited access to a sweet fat diet: lack of withdrawal-like responses. Physiol Behav 107:231-242. CrossRef Medline

Paxinos G, Watson C (2005) The rat brain in stereotaxic coordinates, Ed 5. Amsterdam: Elsevier Academic.

Piccoli L, Micioni Di Bonaventura MV, Cifani C, Costantini VJ, Massagrande M, Montanari D, Martinelli P, Antolini M, Ciccocioppo R, Massi M, Merlo-Pich E, Di Fabio R, Corsi M (2012) Role of orexin-1 receptor mechanisms on compulsive food consumption in a model of binge eating in female rats. Neuropsychopharmacology 37:1999-2011. CrossRef Medline

Selye H (1976) Forty years of stress research: principal remaining problems and misconceptions. Can Med Assoc J 115:53-56. Medline

Shaham Y, Funk D, Erb S, Brown TJ, Walker CD, Stewart J (1997) Corticotropin-releasing factor, but not corticosterone, is involved in stress-induced relapse to heroin-seeking in rats. J Neurosci 17:2605-2614. Medline

Shaham Y, Erb S, Leung S, Buczek Y, Stewart J (1998) CP-154,526, a selective, non peptide antagonist of the corticotropin-releasing factor type 1 receptor attenuates stress-induced relapse to drug seeking in cocaine-and heroin-trained rats. Psychopharmacology 137:184-190. CrossRef Medline

Shaham Y, Erb S, Stewart J (2000) Stress-induced relapse to heroin and cocaine seeking in rats: a review. Brain Res Brain Res Rev 33:13-33. CrossRef Medline

Shalev U, Erb S, Shaham Y (2010) Role of CRF and other neuropeptides in stress-induced reinstatement of drug seeking. Brain Res 1314:15-28. CrossRef Medline

Silberman Y, Winder DG (2013) Emerging role for corticotropin releasing factor signaling in the bed nucleus of the stria terminalis at the intersection of stress and reward. Front Psychiatry 4:42. CrossRef Medline

Sinha R, Shaham Y, Heilig M (2011) Translational and reverse translational research on the role of stress in drug craving and relapse. Psychopharmacology (Berl) 218:69-82. CrossRef Medline

Vale W, Spiess J, Rivier C, Rivier J (1981) Characterization of a 41-residue ovine hypothalamic peptide the stimulates secretion of corticotropin and beta-endorphin. Science 213:1394-1397. CrossRef Medline

Van Pett K, Viau V, Bittencourt JC, Chan RK, Li HY, Arias C, Prins GS, Perrin M, Vale W, Sawchenko PE (2000) Distribution of mRNAs encoding CRF receptors in brain and pituitary of rat and mouse. J Comp Neurol 428:191-212. CrossRef Medline

Wang J, Fang Q, Liu Z, Lu L (2006) Region-specific effects of brain corticotropin-releasing factor receptor type 1 blockade on footshockstress- or drug-priming-induced reinstatement of morphine conditioned place preference in rats. Psychopharmacology 185:19-28. CrossRef Medline

Wise RA, Hoffman DC (1992) Localization of drug reward mechanisms by intracranial injections. Synapse 10:247-263. CrossRef Medline

Yanovski SZ (1993) Binge eating disorder: current knowledge and future directions. Obes Res 1:306-324. CrossRef Medline

Zorrilla EP, Koob GF (2010) Progress in corticotropin-releasing factor-1 antagonist development. Drug Discov Today 15:371-383. CrossRef Medline

Zorrilla EP, Roberts AJ, Rivier JE, Koob GF (2013a) Anxiolytic-like effects of antisauvagine- 30 in mice are not mediated by CRF2 receptors. PLoS One 8:e63942. CrossRef Medline

Zorrilla EP, Heilig M, de Wit H, Shaham Y (2013b) Behavioral, biological, and chemical perspectives on targeting $\mathrm{CRF}(1)$ receptor antagonists to treat alcoholism. Drug Alcohol Depend 128:175-186. CrossRef Medline 